\title{
Light Environment in Tropical Rain Forest of Central Amazonia
}

\author{
W. L. F. BRINKMANN \\ Instituto Nacional de Pesquisas \\ da Amazônia
}

\begin{abstract}
Light intensity above the groundstoreys $(120 \mathrm{~cm})$ and inbetween the ground strata of a Riverine forest, a Carrasco forest and a terra firme Rain forest was recorded through two day periods of time in the rain season (April/May) and the dry season (August) of 1969. Measurements were undertaken between 6 a.m. and 18 p.m. in minute by minute intervals (51.840 readings). The relative frequency of light intensity was computed for seven intensity classes and three periods of time per day. The spectral composition of light was determined as relative frequency of light intensities for five filter ranges of wavelengths, seven intensity classes and three periods of time per day.
\end{abstract}

The riverine forest (best light conditions for the undertorey plant communities) and the terra firme Rain forest (worst conditions) developed extremely oposite positions with respect to forest light climate, while the Carrasco forest showed up with a somewhat intermediate character, but with a strong shift to terra firme Rain forest conditions.

The spectral composition of light received by the ground strata of all three forest stands was as follows: 1) light intensities peaked in the RG 630 filter range of wavelenths $(5.920 \AA-7.500 \AA)$, 2) a secondary intensity peak covered the VG 9 filter $(4.420 \AA-6.440 \AA)$ and 3$)$ a less important secondary peak matched the BG 12 filter band $(3.500 \AA$ $-5.150 \AA$ A).

Inbetween the understorey communities, spectral light intensities were pretty low and showed another considerable red-shift.

\section{INTRODUCTION}

Light is one of the important environmental factors in plant life, primarily, because of the energy supply for photosynthesis. On the other hand, light measurements in plant communities have proved to be full of difficulties. Detailed discussions on all these complex processes and techniques in tropical Rain forest all over the world are refered to by Evans (1939), Evans, Whitmore and Wong ( 1960 ), Grubb \& Whitmore ( 1967 ), Schulz ( 1960 ), and many other authors. As forest structure and light climate are closely related, light environments of three forest stands in central Amazonia where comparitively studied to evaluate their characteristics away from the extremely troublesome forest inventories.

\section{SITE DESCRIPTION}

\section{I - The Riverine forest}

\section{(Ducke Forest Reserve)}

'This forest community follows the small Rain forest streams, i.e. it covers the valley bottoms of the Terciary uplands of Central Amazonia. The canopy heights range from $22 \mathrm{~m}$ to $35 \mathrm{~m}$, but all canopy strata are either poorly defined or not formed at all. The canopy area is shot with epiphytes, trailing lianas, Bromeliaceae and Orchidaceae. The dominant tree species belong to families, as Leguminoseae, Sapotaceae and Moraceae. This forest type is refered to by Takeuchi (1961) as "Rain forest on the low terra firme". A $30 \mathrm{~m} \times 30 \mathrm{~m}$ inventory recorded 57 trees $(10 \mathrm{~cm}$ to $25 \mathrm{~cm} \mathrm{DBH}$ ) and 13 trees (above $25 \mathrm{~cm}$ $\mathrm{DBH})$, including some palm trees. The crown projection areas for both diameter classes are shown in Figure 1. 


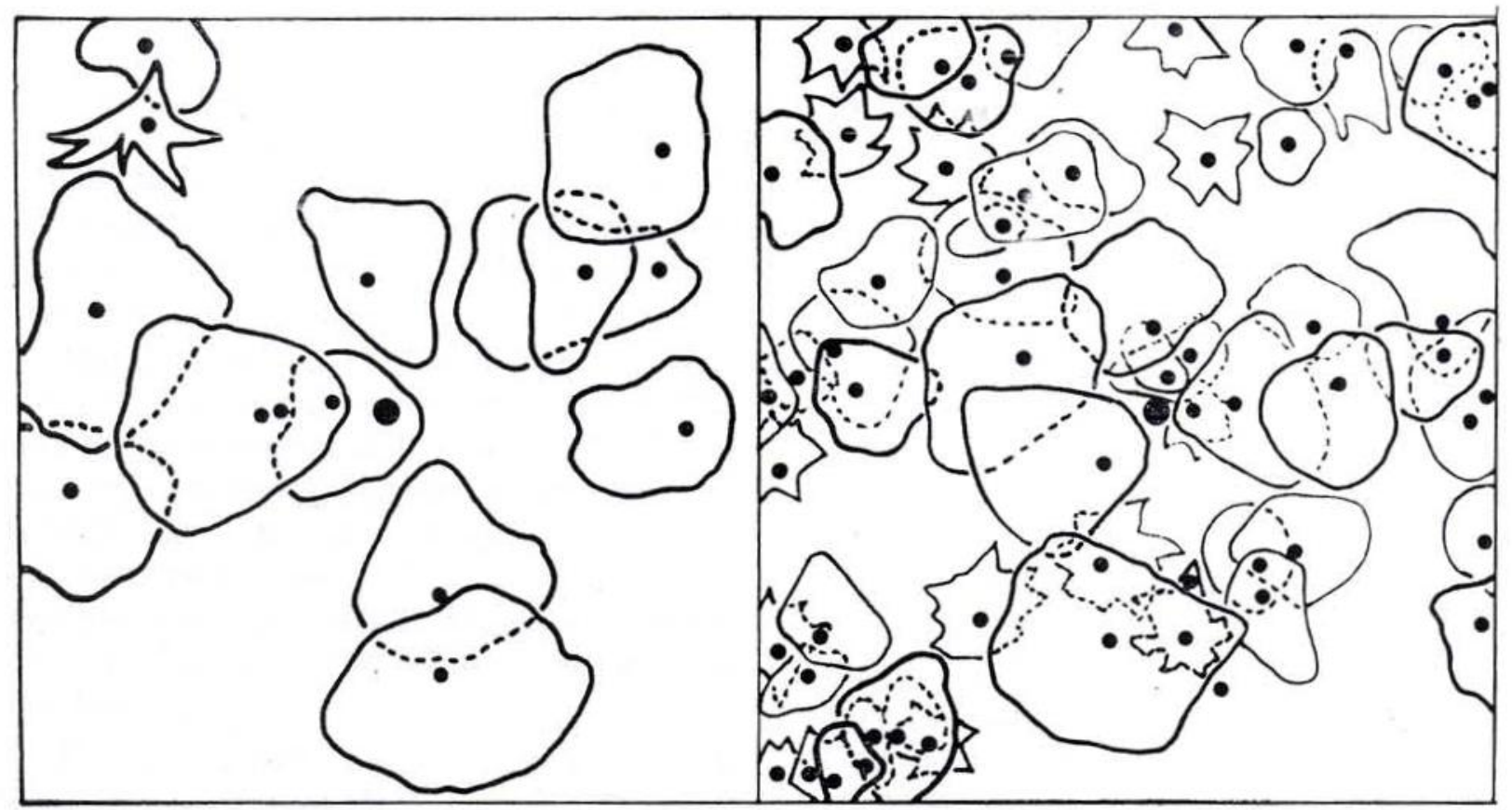

Figure 1 - Crown projection areas of a Riverine forest at Ducke Forest Reserve, Km 26 of the Manaus-Itacoatiara Road, Central Amazonia $(30 \mathrm{~m} \times 30 \mathrm{~m}$ plot). Left: all stemdiameter classes above. $25 \mathrm{~cm} \mathrm{DBH}$; all diameter classes below $25 \mathrm{~cm}$ DHB. - Sampling site.

The ground stratum consists of stemless palms, herbaceous plant communities and some seedlings and saplings, which form a dense ground cover. The herbaceous community was classified by Takeuchi (1961) as Hymenophyllaceae, Polypodeaceae, Lycopodiaceae, Bromeliaceae, Maranthaceae, Rapateaceae, Araceae and Orchidaceae. Very common palms are : Astrocaryum sp., Oenocarpus spp, Attalea sp and Euterpe oleracea.

The soils are of the sandy riverine complex with some humus accumulation in the upper $15 \mathrm{cms}$ of the soil profile. The groundwater tabel is quite high the year round. During, or shortly after heavy downpours, the forest floor is temporarily flooded by rain water surplus.

\section{II - The Carrasco forest}

\section{(Ducke Forest Reserve)}

The Carrasco forest under study covers a river terrace like slope of the Igarapé Barro Branco valley. The forest community must be understood as an intermediate forest stand between the terra firme Rain forest and the Riverine forest. Takeuchi (1961) described a similar forest as "inclined terra firme Rain forest" ( $\mathrm{Km} 42$ of the Manaus-Itacoatiara Road). The term Carrasco forest used, does not exactly match the definition of this particular forest type as refered to by Aubréville (1961).

Canopy heights range from $22 \mathrm{~m}$ to $32 \mathrm{~m}$. including some emergent trees (Hymenelobium exelsum Ducke). The canopy strata are up to a certain extend well defined. The dominant tree species are Protium spp and Eschweilera spp. A $30 \mathrm{~m} \times 30 \mathrm{~m}$ inventory recorded 35 trees $(10 \mathrm{~cm}$ $-25 \mathrm{~cm} \mathrm{DBH}$ ) and 20 trees (above $25 \mathrm{~cm} \mathrm{DBH}$ ) respectively. The canopy projection areas of both diameter classes are shown in Figure 2. Epiphytes, Bromeliaceae and Orchidaceae are less abundant than at the Riverine Forest. The understorey consists of numerous seedlings and saplings, some herbaceous plants and very small palms.

The soils are of the latosolic complex, but contain a considerable sand fraction all over the profile. 
III - The terra firme Rain forest

\section{(Ducke Forest Reserve)}

The terra firme Rain forest under study is a typical climax forest of the Tertiary formations of Central Amazonia. This particular forest community cover the chapadas along the Manaus-Itacoatiara Road and was preliminary inventorized by Rodrigues (1967). The dominant tree species of the 137.000 ha forest inventory (all stemdiameter classes above 25 cm DBH) are : Eschweilera spp. (6.5 trees/ ha), Scleronema micranthum Ducke (3.4 trees/ha), Corythopora alta Knuth (2.9 trees/ ha) and Ragala spuvia (Ducke) Aubr. (2.2 trees/ha).

Takeuchi (1961) proved, that more than 40 percent of all trees above $10 \mathrm{~cm}$ in diameter (DBH) belonged to three families: a) Leguminosae, b) Lecythidaceae, and c) Sapotaceae. The total number of trees for a $1.600 \mathrm{~m}^{2}$ inventory was computed with 123 trees. These results match pretty well those of the Rodrigues inventory at least as far as families are concerned.
The dominant tree species at the "chapadas" of the Ducke Forest Reserve are Eschweilera spp (8.2 trees/ha) and Scleronema micranthum Ducke (35 trees/ha). The forest inventory covered an area of 36 ha (Aubréville, 1961).

The canopy heights range from $25 \mathrm{~m}$ to $35 \mathrm{~m}$ and all three strata are considerably well developed. Epiphytes, Bromeliaceae and Orchidaceae are less abundant than in the Riverine forest, but outmatch the Carrasco forest. Trailing lianas are quite common. The crown projection areas of various diameter classes are refered to in Figure 3.

The "shrub" - stratum is obviously dominated by palms, as Astrocaryum mun baca, Syagrus inajai, Bactris sp. et. al and various saplings. The groundstratum is covered with spots of seedlings, some stemless palms, as Oenocarpus spp., Scheelea sp., Orbygnia spectabilis, and a few herbs of the families Cyperaceae, Maranthaceae and Orchidaceae. Soils are of the heavy of very heavy latosols, which cover about 85 percent of the Terciary uplands along the ManausItacoatiara Road (IPEAN, 1969).

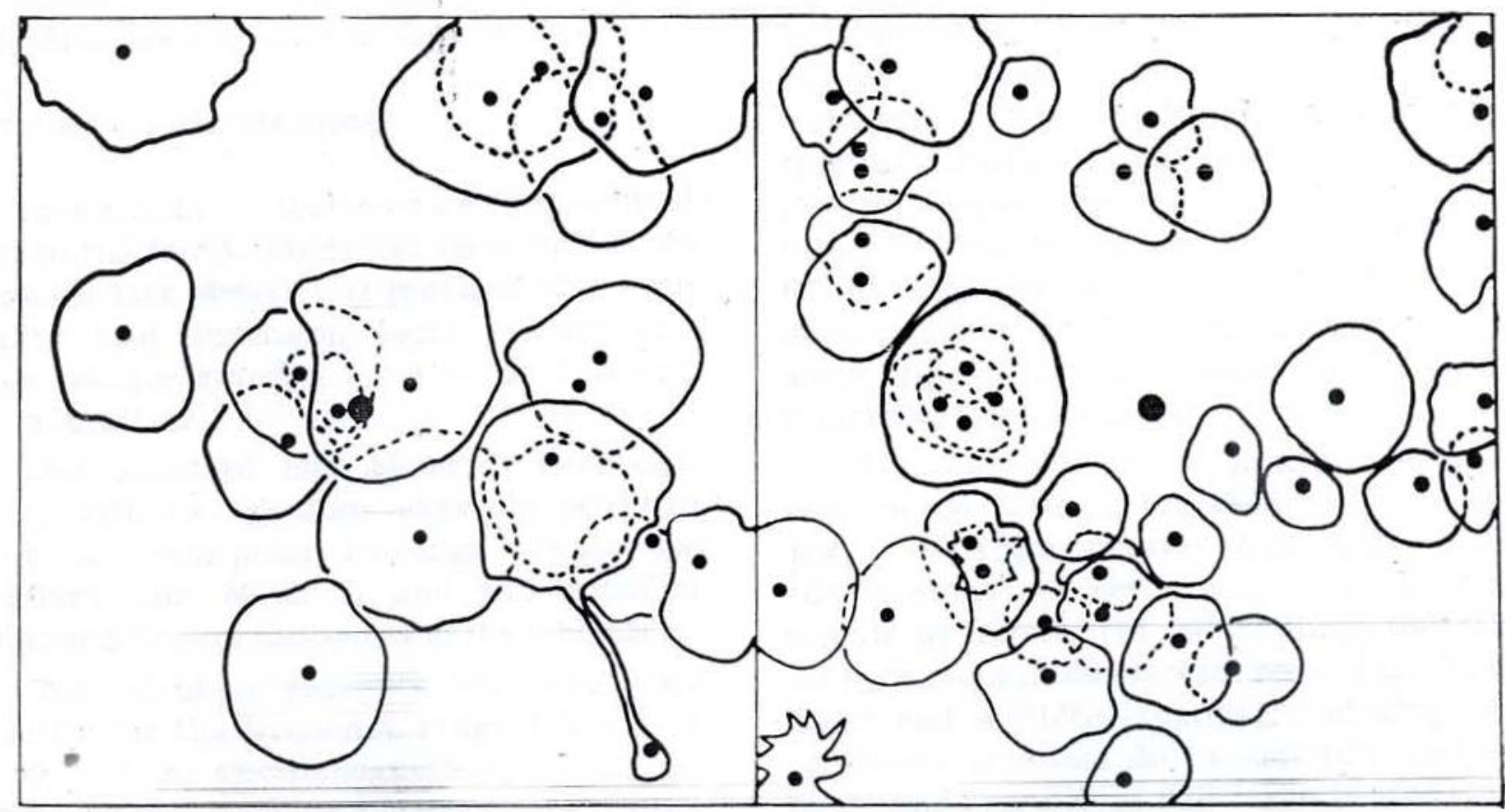

Figure 2 - Crown projection areas of a Carrasco forest at Ducke Forest Reserve, $\mathrm{Km} 26$ of the Manaus-Itacoatiara Road, Central Amazonia $(30 \mathrm{~m} \mathrm{x} 30 \mathrm{~m}$ plot). Left : all stemdiameter classes above $25 \mathrm{~cm}$ DBH; Right : all stemdiameter classes below $25 \mathrm{~cm}$ DBH. Sampling site. 


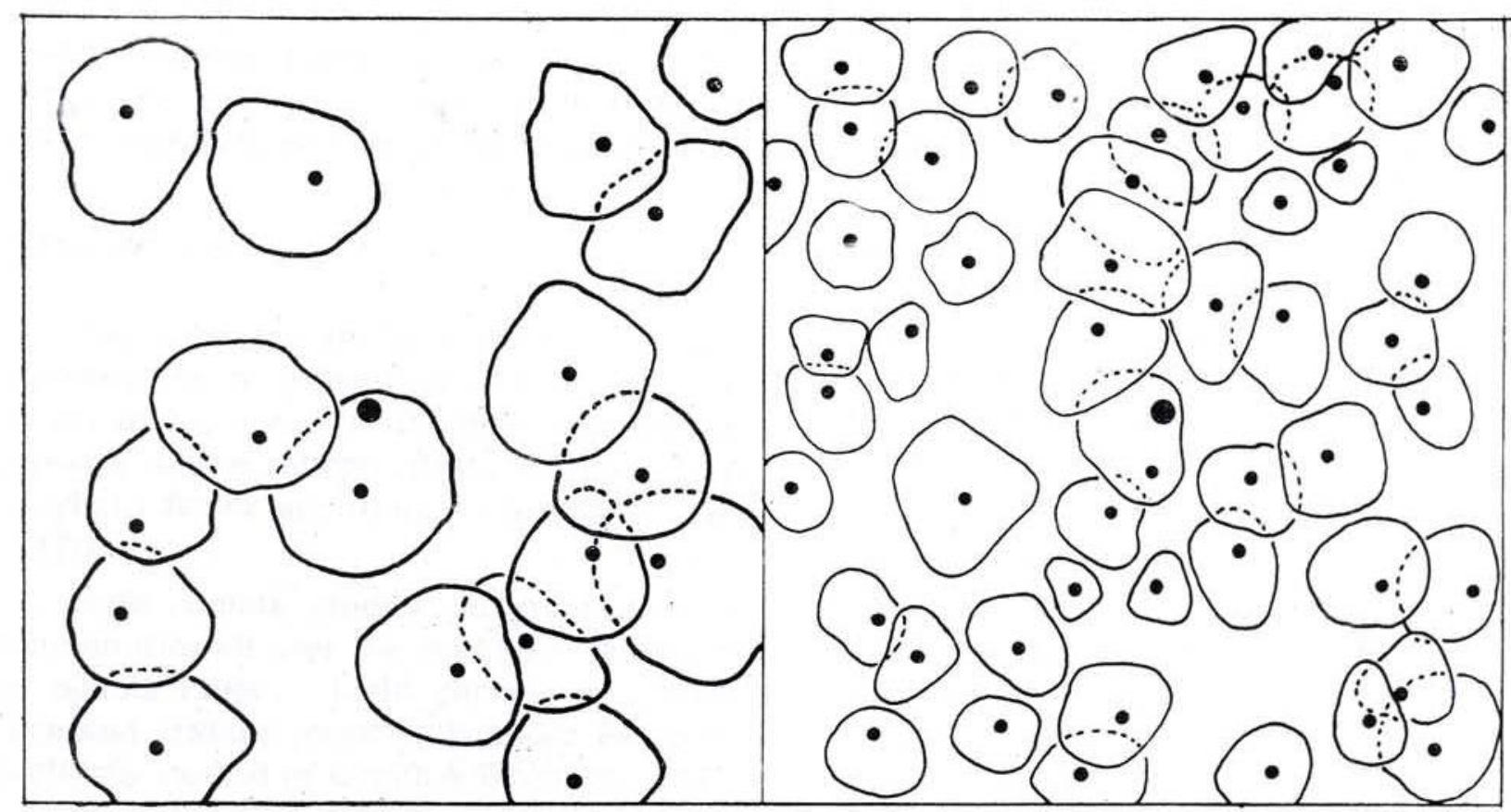

Figure 3 - Crown projection areas of a terra firme Rain forest at Ducke Forest Reserve, Km 26 of the ManausItacoatiara Road, Central Amazonia (30 m x $30 \mathrm{~m}$ plot). Left : all stemdiameter classes below $25 \mathrm{~cm}$ DBH. - Sampling site.

All three stands are extremely heterogenous and sofar, difficult to handle with as far as representativeness of some small plots for the total are concerned. This fact should be always under consideration when data evaluation are discussed in this paper.

\section{INSTRUMENTS AND METHODS}

Incident direct, scattered and transmitted light in the forest stands was recorded by two Standard Lux Meter II, 1) provided with high quality taut supension band systems and range selector switches for $0-100 \mathrm{Lux}$ and $0-1.000$ Lux.

The Standard Lux Meter II were connected with six selenium elements $\mathbf{S} 60^{(1)}$ in spray - waterproof housings. Both, the Standard Lux Meter II and the selenium elements $\mathbf{S} 60$ were calibrated in the laboratory.

The selenium elements $\mathbf{5} 60$ used were sensitive for the frequency range $3.500 \AA$ to $7.200 \AA$ of the electromagnetic spectrum; i.e. the receptors cover practically the entire range of wavelengths with importance in plant physiology.

About $120 \mathrm{~cm}$ above the forest floor, the selenium elements S60 were mounted face up on tripods. One element measured total light intensity at the above level, supplied with a clipped-on platinum opague filter (light absorbance: 1:10) whenever neccessary. The spectral distribution of light intensities was recorded by five elements with clipped-on glass filters (2). The filters used are : BG 12, VG 9, RG 630, RG 665 and RGN 9. Detailed information about relative transmittance of the above filters, etc. is refered to by Jenaer Glaswerke Schott (1962).

Two day periods of measurements for each stand were undertaken in April and May, 1969 (rain season) and August, 1969 (dry season) between 6 a.m. and 18 p.m. minute by minute ( 51.840 readings over all). All light measurements were related to : 1) full direct and scattered sunlight, including hazy conditions (reduced direct, but full scattered light) and 2) scattered light (sun behind dense

(1) - Fa. B. Lange, Berlin, Germany

(2) - F. Jenaer Glaswerke Schott \& Gen., Mainz Germany. 
clouds). The overcast was estimated in fraction of one tenth, simultanously whith light measurements. These estimates are rather tentative because of the limited view.

\section{PAPER REVIEW}

The light climate in a forest is usually expressed as a percentage of total light intensity in the open; i.e. the light interception capacity of the canopy strata is determined (daylight factor according to Atkins, et. al. (1937) .

Light climate studies on tropical forest communities all over the world are refered to by Schulz (1960). Light climate of a montane and lowland forest in Ecuador was comparitively studied by Grubb \& Whitmore (1967).

For the Amazon basin, forest light readings were taken by Ashton (1958) near Santarém in a probably old secondary Rain forest. Kanwisher (3) (1967) stated the daylight factor of the Amazonian Rain forest to be in the order of 4. to 8. percent. Alvim (3) (1967) calculated the average light intensity for a Rain forest near the Rio Negro - Rio Branco junction with 1.35 percent. Coutinho, Lamberti (3) (1967) reported the daylight factor for a terra firme Rain forest to be 0.5 to 1.0 percent. Comprehensive light climate evaluations by Loomis, Williams and Moraes (1967) recorded the daylight factor for two terra firme Rain forest sites near Belém with 1.1 percent and 1.5 percent, for a secondary forest (capoeira) with 1.8 percent, for an Igapó transect with 3.7 percent and for a varzéa forest community with 1.0 percent. Williams $^{(3)}$ et. al. (1967) studied the light environment of a flooded forest (Igapó) and a terra firme Rain forest near the confluence of the Rio Negro with the Rio Branco. The penetrating light intensity was 4.2 percent and 1,1 percent, respectively. Brinkmann (1970d) reported the daylight factor for a dense capoeira near Manaus with 0.7 to 1.9 percent, while the "spectral" daylight factor was : BG $12-0.7$; VG $9-1.1$; RG $630-$ 1.5; RG $665-2.6$ and RGN $9-3.0$ ( 3 day average) .

All these evaluations confirm the fact, that daylight factor is really of little use in comparative studies on various forest communities because the fractionizing effect is to small to be significant. On the other hand, the ratio total light (open) to total light (forest) has no ecological meaning at all.

\section{RESUlts AND DISCUSSION}

The evaluation of light intensities as an important ecological complex in forest life and natural forest regeneration cycles has to answer to following questions : 1) which total light and spectral light intensities are supplied to a particular forest stratum ? and 2) how are these light intensities distributed over time?

The complex vertical structure and heterogenity of the tropical Rain forest sites under study, as well as the short time variations of total light intensity above the canopies, and in consequence in the stands, required the great population of light measurements (total readings: 51.840 ), to define the particular light climate at the particular forest plot. All available light intensities at about $120 \mathrm{~cm}$ above the ground of all three sites were recorded by scanning the random light surplus gradually from deep shade light to full direct sunlight (sunflecks). The appropriate statistical avaluation of the obtained data populations was the relative frequency distribution of light intensities, as "abnormally" high sunfleck readings did not carry undue weight.

The relative frequencies of light intensities for all three forest stands, as 1) the Riverine forest, 2) the Carrasco forest, and 3) the terra firme Rain forest were computed for seven intensity classes and three periods of time per day (see Table 1).

(3) - Unpublished report on the R/V Alpha Helix Amazon Expedition, February to October, 1967. 
The evaluation of all results presented in Table 1 confirm the well developed individuality of the three forest stands, as far as light climates are concerned. While the Riverine forest (best light conditions) and the terra firme Rain forest (worst light conditions) show extremely opposite positions, the Carrasco forest has an intermediate character, but with a very strong shift to the terra firme Rain forest conditions, i.e. the latter forest types are similar structured.

Between 6 a.m. and 10 a.m. 94 percent of all light readings at the terra firme Rain forest site are below the 200 Lux level, while the corresponding percentages for the Carrasco forest and Riverine forest are 63 percent and 36 percent. A similar, but less extreme situation was calculated for the period of time between 14 p.m. and 18 p.m. The corresponding percentages are 66 percent, 71 percent and 34 percent. Minimium conditions for the photosynthetical response of various plants of the ground stratum are assumed to be at about 200 Lux. Very short bursts of intensive light (sunflecks), which are scarcely important for the $\mathrm{CO}_{2}$ assimilation of the plants are recorded for the terra firme Rain forest (morning : no cvent; afternoon: 1 percent) and the Carrasco forest (morning: 5 percent; afternoon : 1 percent). As a matter of fact, these minimum conditions are one of the growth rate regulatives of the groundstratum, a selective principle for species present, but at no time a mass development restriction for seedlings and saplings. These assumptions match pretty well growth rate determinations by Pires (1966). The growth rates for saplings in the ground stratum of a terra firme Rain forest site near Belém were extremely low. The same was observed by Vieira (verbal communication) for rosewood saplings at a terra firme Rain forest plot near Santarém. Rosewood saplings of the understorey with thirty five years of age were about $60 \mathrm{~cm}$ high. The $200 \mathrm{Lux}$ photosynthetical response limit for understorey plants cannot be generalized, but is rather significant. Only some species (some tree seedlings and obviously some herbs) of the ground stratum have lower compensation

\begin{tabular}{|c|c|c|c|c|c|c|c|c|c|}
\hline & FOREST TYPE & $0-49$ & $50-99$ & $100-199$ & 200.299 & $300-399$ & $400-499$ & $>500$ & Lux \\
\hline \multirow{3}{*}{ 远 } & Riverine Forest & 14 & 8 & 14 & 12 & 8 & 31 & 13 & \\
\hline & Carrasco Forest & 30 & 16 & 17 & 12 & 10 & 10 & 5 & \\
\hline & Terra firme Rain Foresi & 31 & 37 & 26 & 4 & 1 & 1 & - & \\
\hline \multirow{3}{*}{ 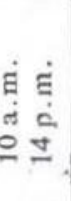 } & Riverine Forest & - & - & - & - & 1 & 7 & 92 & \\
\hline & Carrasco Forest & - & 2 & 6 & 33 & 15 & 21 & 23 & \\
\hline & Terra firme Rain Forest & - & - & 15 & 39 & 26 & 16 & 4 & \\
\hline \multirow{3}{*}{ 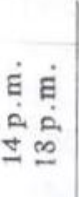 } & Riverine Forest & 11 & 8 & 15 & 13 & 11 & 5 & 37 & \\
\hline & Carrasco Forest & 35 & 14 & 22 & 22 & 4 & 2 & 1 & \\
\hline & - Terra firme Rain Foresi & 32 & 14 & 20 & 14 & 16 & 3 & 1 & \\
\hline
\end{tabular}

TABLE 1 - Relative frequency of light intensities above the ground stratum (120cm) of 1) a Riverine forest 2) a Carrasco forest and 3) a terra tirme Rain forest (Ducke Forest Reserve, central Amazonia) for seven intensity classes and three periods of time per day. 
points than 200 Lux. Coutinho, Lamber$\mathrm{ti}^{(3)}$ (1967) reported on some investigations at a terra firme Rain forest near the Rio Negro - Rio Branco junction, where plants of the understorey photosynthesized in the early morning just below the 200 Lux level.

Even between 10 a.m. and 14 p.m., the terra firme Rain forest (15 percent) and the Carrasco forest ( 8 percent) reported light intensities below 200 Lux. Above the 500 Lux level, the relative intensity frequencies were characteristical for the particular forest types (Riverine forest - 92 percent; Carrasco forest ( 23 percent), and terra firme Rain forest (4 percent). The ecological meaning of these results are quite significant. While the Riverine forest received a more or less continuous light surplus during the four hours period of time, the terra firme Rain forest was flashed occasionally by intensive light bursts (sunflecks). Although the percentage for the Carrasco forest is considerably higher, only a small fraction of the light surplus are longer lasting sunflecks. According to Schulz (1960) at higher light intensities the photosynthetical response of the plants tends to approach a constant value far below the maximum intensity. This fact reduces sunfleck light efficiency to a very minimum. On the other hand, at low intensity levels the photosynthetical response of many plants is somewhat proportional to light intensity, i.e that for the terra firme Rain forest and up to some extend for the Carrasco forest assimilation processes are prevailingly limited to the 10 a.m. to 14 p.m. period of time (see Table 1).

Sunfleck intensities change rapidly. Readings as high as 45.000 Lux were obtained for the Riverine forest. The maximum sunfleck intensity recorded for the Carrasco forest and the terra firme Rain forest were 12.000 Lux and $\mathbf{5 . 8 0 0}$ Lux respectively. According to Alvim 3) (1967) readings as high "as $60.000-80.000$ Lux could sometimes be obtained.

When sunfleck light lasted long enough seedlings of several tree species at a Suriname
Rain forest site were observed to grow vigorously. (Schulz, 1960). The seedlings covered a patch in the forest which received direct sunlight through a small hole in the canopy during about 40 minutes per day. For the rest of the day light intensity was about the same as in neighbouring spot.

Following the light climate analyses stated above, the most significant event in the tropical Rain forest is the collapse of large emergent trees. According to Schulz (1960) seedlings and saplings of a number of tree species reach their maximum growth rates. when exposed to full sun light. An intensive, but qualitative study on the factor light as a basic element in tree growth at the Ducke Forest Reserve was carried out by Araujo (1970). Maximum growth rates in full sun light were recorded for: Carapa guianensis Aubl., Cedrelinga catenaeformis Ducke, Calophyllum brasiliense Com., Jacaranda copaia (Aubl.) D. Don and Bayassa guianense Aubl.. Survival of species depends therefore on a serious "forest accident", which opens the canopies, and great amounts of seedlings in waiting position, i.e. a high reproductive capacity.

Coincidently with light intensitity measurements spectral light intensity readings were taken to compute the spectral composition of the forest light climates. For all three forest sites under, study, the spectra] light intensities for five filter ranges, seven intensity classes and three periods of time per day were calculated as relative frequencies of spectral light intensities (see Table 2).

The evaluation of spectral light intensities obtained for all three forest types (Table 2), confirm the following suggestions : 1) light intensity peaked in the filter RG 630 range of wavelenths (5.920 $-7.500 \AA)$, 2) a secondary intensity peak covered the filter VG 9 region $(4.420 \AA-6.440 \AA$ ) and, 3 ) a less pronounced secondary peak matched the filter BG 12 range of wavelenths ( $3.550 \AA$ $5.150 \AA$ ). Between 6 a.m. and 10 a.m. the intensity of spectral light for all filter regions is almost completely below $300 \mathrm{Lux}$. The differ- 


\begin{tabular}{|c|c|c|c|c|c|c|c|c|c|c|c|c|c|c|c|c|c|c|c|c|c|c|}
\hline \multirow{2}{*}{$\begin{array}{l}\text { FORI } \\
\text { TIME }\end{array}$} & \multirow{2}{*}{$\begin{array}{l}\mathrm{ST}_{\text {* TYPES }} \\
\text { FILTERS }\end{array}$} & \multicolumn{5}{|c|}{ RIVERINE FOREST } & \multicolumn{2}{|c|}{$[\mathrm{LUX}]$} & \multirow[b]{2}{*}{$\begin{array}{r}0 \\
49\end{array}$} & \multicolumn{2}{|c|}{ CARRASCC } & \multicolumn{2}{|c|}{ FOREST } & \multicolumn{2}{|c|}{$[$ LUX] } & \multicolumn{2}{|c|}{ TERRA } & \multirow{2}{*}{$\begin{array}{c}\text { FIRME } \\
\begin{array}{c}100 \\
199\end{array}\end{array}$} & \multirow{2}{*}{$\begin{array}{l}\text { RAIN } \\
200 \\
299\end{array}$} & \multicolumn{2}{|c|}{ FOREST } & \multirow{2}{*}{$\begin{array}{l}{[\mathrm{LUX}]} \\
>500\end{array}$} \\
\hline & & $\begin{array}{c}0 \\
49\end{array}$ & $\begin{array}{l}50 \\
99\end{array}$ & $\begin{array}{l}100 \\
199\end{array}$ & $\begin{array}{l}200 \\
299\end{array}$ & $\begin{array}{l}300 \\
399\end{array}$ & $\begin{array}{l}400 \\
499\end{array}$ & $>500$ & & $\begin{array}{l}50 \\
99\end{array}$ & $\begin{array}{l}100 \\
199\end{array}$ & $\begin{array}{l}200 \\
299\end{array}$ & $\begin{array}{l}300 \\
399\end{array}$ & $\begin{array}{l}400 \\
499\end{array}$ & $>500$ & $\begin{array}{r}0 \\
49\end{array}$ & $\begin{array}{l}50 \\
99\end{array}$ & & & $\begin{array}{l}300 \\
399\end{array}$ & $\begin{array}{l}400 \\
499\end{array}$ & \\
\hline \multirow{5}{*}{ 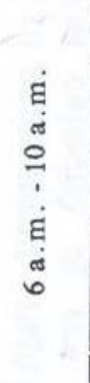 } & BG 12 & 42 & 21 & 36 & 1 & - & - & - & 64 & 28 & 8 & - & - & - & - & 91 & 6 & 3 & - & - & - & - \\
\hline & VG 9 & 36 & 26 & 29 & 9 & - & - & - & 57 & 17 & 25 & 1 & - & - & - & 82 & 18 & - & - & - & - & - \\
\hline & RG 630 & 38 & 14 & 24 & 22 & 2 & - & - & 43 & 9 & 20 & 23 & 4 & 1 & - & 46 & 10 & 24 & 18 & 2 & - & - \\
\hline & RG 665 & 96 & 4 & - & - & - & - & - & 99 & 1 & - & - & - & - & - & 100 & - & - & - & - & - & - \\
\hline & RGN 9 & 100 & - & - & - & - & - & - & 100 & - & - & - & - & - & - & 100 & - & - & - & - & - & - \\
\hline \multirow{5}{*}{ 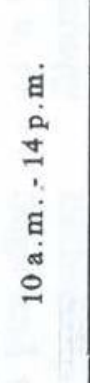 } & BG 12 & - & 2 & 27 & 47 & 14 & 4 & 6 & 18 & 32 & 44 & 1 & 2 & - & 2 & 4 & 65 & 26 & 2 & - & 1 & 2 \\
\hline & VG 9 & - & 3 & 3 & 31 & 28 & 10 & 25 & 23 & 11 & 53 & 8 & 2 & 2 & 1 & 3 & 38 & 52 & 4 & - & - & 3 \\
\hline & RG 630 & - & 1 & 3 & 14 & 29 & 33 & 20 & 5 & 5 & 11 & 21 & 15 & 7 & 36 & - & - & 7 & 10 & 18 & 7 & 58 \\
\hline & R.G 665 & 19 & 74 & - & - & - & - & - & 99 & 1 & - & - & - & - & - & 97 & 2 & 1 & - & - & - & - \\
\hline & RGN ? & 92 & 7 & 1 & - & - & - & - & 99 & 1 & - & - & - & - & - & 99 & - & - & - & - & 1 & - \\
\hline \multirow{5}{*}{ 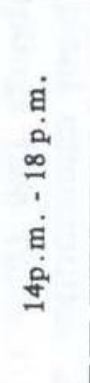 } & BG 12 & 35 & 38 & 15 & 5 & 4 & - & 3 & 62 & 34 & 2 & 2 & - & - & - & 52 & 32 & 16 & - & - & - & - \\
\hline & VG 9 & 34 & 30 & 19 & 3 & 4 & - & 10 & 49 & 34 & 13 & 1 & 2 & - & 1 & 50 & 22 & 24 & 3 & 1 & - & - \\
\hline & RG 630 & 27 & 11 & 38 & 5 & - & 4 & 15 & 38 & 13 & 27 & 13 & 7 & 1 & 1 & 29 & 12 & 24 & 14 & 5 & 10 & 6 \\
\hline & RG 665 & 80 & 20 & - & - & - & - & - & 100 & - & - & - & - & - & - & 100 & - & - & - & - & - & - \\
\hline & RGN 9 & 99 & - & 1 & - & - & - & - & 100 & - & - & - & - & - & - & 100 & - & - & - & - & - & - \\
\hline
\end{tabular}

TABLE 2 - Relative frequency of spectral light intensities above the ground stratum $(120 \mathrm{~cm})$ of 1) a Riverine forest, 2) a Carrasco forest and 3) a terra firme Rain forest (Ducke Forest Reserve), central Amazonia) for five filter ranges of wavelenghts, seven intensity classes and three periods of time per day. 
"nt forest types were well characterized by spectral light intensity recorded for the BG 12 and VG 9 filter bands. The relative frequen$c y$ of all light intensity measurements below the 100 Lux level were: for the Riverine forest (BG $12-63 \%$; VG $9-72 \%$ ), the Carrasco forest (BG $12-92 \%$; VG $9-74 \%$ ) und, for the terra firme Rain forest (BG 12 $97 \%$; VG $9-100 \%$ ). The appropriate values between 14 p.m. and 18 p.m. were : (BG $12-73 \%$ ); VG $9-64 \%$ ), (BG $12-$ $96 \%$; VG $9-83 \%$ ) and (BG $12-84 \%$; VG $9-72 \%$ ), i.e. light intensity levels for both particular filter regions were quite similar and low. For both filter bands, the light interception by the canopy strata of the Carrasco forest and terra firme Rain forest increased slightly, but decreased extremely for the Riverine forest, where about 95 percent (BG $12-98 \%$; VG $9-94 \%$ ) of all light measurements were above the 200 Lux level. As shown above (Table 1), the well formed and dense canopy strata of the Carrasco forest and the terra firme Rain forest cut out widely the blue fraction of the spectrum, i.e. direct and scattered sunlight. On the other hand, the hardly defined canopy strata of the Riverine forest, perforated by gaps and openings, was widely open for diffuse skylight and bright sunflecks.

All the day long spectral light intensity peaked in the RG 630 filter region. In the morning ( 6 a.m. to 10 a.m.) and the afternoon (14 p.m. to 18 p.m.) about $25 \%$ to $35 \%$ of all recorded light measurements were above the 200 Lux level for all three forest types, and values increased to $85 \%$ to $95 \%$ of total readings during the 10 a.m. to 14 p.m. period of time. The intensity distribution of RG 630 filtered light was for all three forest stands most in the same order of magnitude. Ineident direct and scattered sunlight is multiply scattered and transmitted by leaves or branches, when passing through the canopy strata. Coincidently the spectral composition of the light is change depending on the wavelenth selection capacity of the canopy area. According to Brinkmann (1970 a, b, c) the peaks for scattered reflection and scattered transmission on leaves of some tropical tree species considering both sides matched exactly the RG 630 filter region. The same counted for branches and stems. The species studied were: Carapa guianensis Aubl., Swietenia macrophylia King, Scleronema micranthum Ducke, Virola spp. Protium spp. and Eschweilera spp., i.e. all species were common in the forests under survey.

At all three sites, the spectral light intensity for the RG $665(6.350 \AA-7.800 \AA)$ and RGN $9(6.500 \AA-8.200 \AA)$ filter regions did scarecely exceed the 50 Lux level all the day long. This may be due to a considerable decrease in sensitivity of the selenium elements S60 above $7.000 \AA$.

The light climate of the Riverine forest, the Carrasco forest and the terra firme Rain forest about $120 \mathrm{~cm}$ above the forest floor was studied and analyzed above, i.e. the total light intensity and the spectral composition of light received by the understorey plant communities. The following light intensity determinations were undertaken to evaluate the spectral composition of light inbetween the ground strata of all the forest types under minimum conditions, i.e. days without or mostly without full direct sunlight. Scattered light in the groundstorey was measured by means of five selenium elements $\mathbf{S} 60$, mounted face down on tripods about $120 \mathrm{~cm}$ above the forest floor. The spectral composition of understorey light climate was studied by clipped-on glass filters as used above. Readings were done in five minute intervals over a three days period of time during the rain season of 1969 (May) for all three forest types. The vegetation of the ground strata was tentatively inventorized by 10 plots on a $2 \mathrm{~m} \times 2 \mathrm{~m}$ grid. These plots were selected at random around the sampling stations. Up to $100 \mathrm{~cm}$ height all plants were sampled and fractionized into: 1) palm communities, 2) herbaceous plant communities, and 3 ) seedlings and saplings (see Table 3 ). 
Riverine Forest

\begin{tabular}{|c|c|c|c|c|c|c|c|c|c|c|c|c|}
\hline plots & I & II & III & IV & V & VI & VII & VIII & IX & $\mathrm{X}$ & average & total \\
\hline palm communities & 15 & 28 & 5 & 7 & 8 & 12 & 17 & 29 & 23 & 21 & 16 & 165 \\
\hline nerb communities & 14 & 128 & 11 & 53 & 44 & 43 & 19 & 36 & 46 & 53 & 45 & 446 \\
\hline seedlings/saplings & 52 & 27 & 38 & 61 & 52 & 27 & 62 & 34 & 48 & 38 & 44 & 439 \\
\hline Total & 81 & 183 & 54 & 121 & 104 & 82 & 98 & 99 & 117 & 112 & 105 & 1051 \\
\hline
\end{tabular}

Carrasco Forest

palm communities

herb communities

seedlings/saplings

$\begin{array}{rrrrrrrrrrrr}3 & 3 & 3 & 6 & 5 & 5 & 5 & 11 & 13 & 16 & 7 & 70 \\ 14 & 12 & 4 & 5 & 8 & 4 & 11 & 3 & 9 & 7 & 8 & 77 \\ 90 & 127 & 59 & 52 & 55 & 52 & 107 & 66 & 83 & 60 & 75 & 751 \\ 107 & 142 & 66 & 63 & 68 & 61 & 123 & 80 & 105 & 83 & 90 & 898\end{array}$

Total

Terra firme Rain forest

palm communities

herb communities

$\begin{array}{llllllllllll}2 & 4 & 3 & 5 & 7 & 6 & 12 & 6 & 9 & 12 & 7 & 66\end{array}$

seedlings/saplings

$\begin{array}{llllllllllll}9 & 19 & 5 & 13 & 5 & 8 & 9 & 6 & 5 & 8 & 9 & 87\end{array}$

\begin{tabular}{ccccccccccccc} 
Total & 78 & 57 & 92 & 58 & 48 & 62 & 73 & 48 & 58 & 77 & 66 & 651 \\
\hline \hline TABLE 3 - Ground strata vegetation inventory for 1) & Riverine forest, 2) & a Carrasco forest and 3) & a terra fir-
\end{tabular}

$\begin{array}{llllll}67 & 34 & 84 & 40 & 36 & 48\end{array}$

$\begin{array}{llllll}52 & 36 & 44 & 57 & 50 & 498\end{array}$
me Rain forest. (Ducke Forest Reserve, central Amazonia).

The Riverine forest had about twice as much palms in the ground stratum as the Carrasco forest or the terra firme Rain forest, which did not shown any great differences in the total number. The same distribution pattern showed up with the herbaceous plant community, only that the Riverine forest reported about five times as much herbs. Seedlings and saplings were the dominant fraction of groundstorey vegetation for the Carrasco forest and the terra firme Rain forest (five to ten times higher in total number of plants than counted for the herb, and palm communities). The abundance of seedlings and saplings on the waiting list indicate the high potential reproductive capacity of these forest types, where light is the key factor to release the supressed ground stratum communities.

During the periods of readings the sky was completely covered with clouds and no sunflecks were observed on the ground. Every day, some rain was recorded.
Spectral light intensities in the plant communities of the ground strata on all three forest stands were extremely low. For the BG 12, VG 9 and RGN 9 filter bands the intensities ranged from no light tracable up to 10 Lux. An intensity peak was recorded for the RG 630 filter region (up to $60 \mathrm{Lux}$ ), which was joint by a secondary peak for the RG 665 filter range of wavelengths (up to 20 Lux). In comparison to the spectral light above the groundstorey an increase in the red part of the spectrum was observed, while the secondary peak in the short wavelenths disappeared (BG 12 - blue). During interception and reflection/transmission processes in the groundstorey plant communities the just observed red shift of spectral light under the forest canopy strata was intensified due to the above described scattered reflection and transmission peaks on leaf surfaces and barks, which cover the RG 630 filter region (Brinkmann, $1970 \mathrm{a}, \mathrm{b}, \mathrm{c}$ ). 


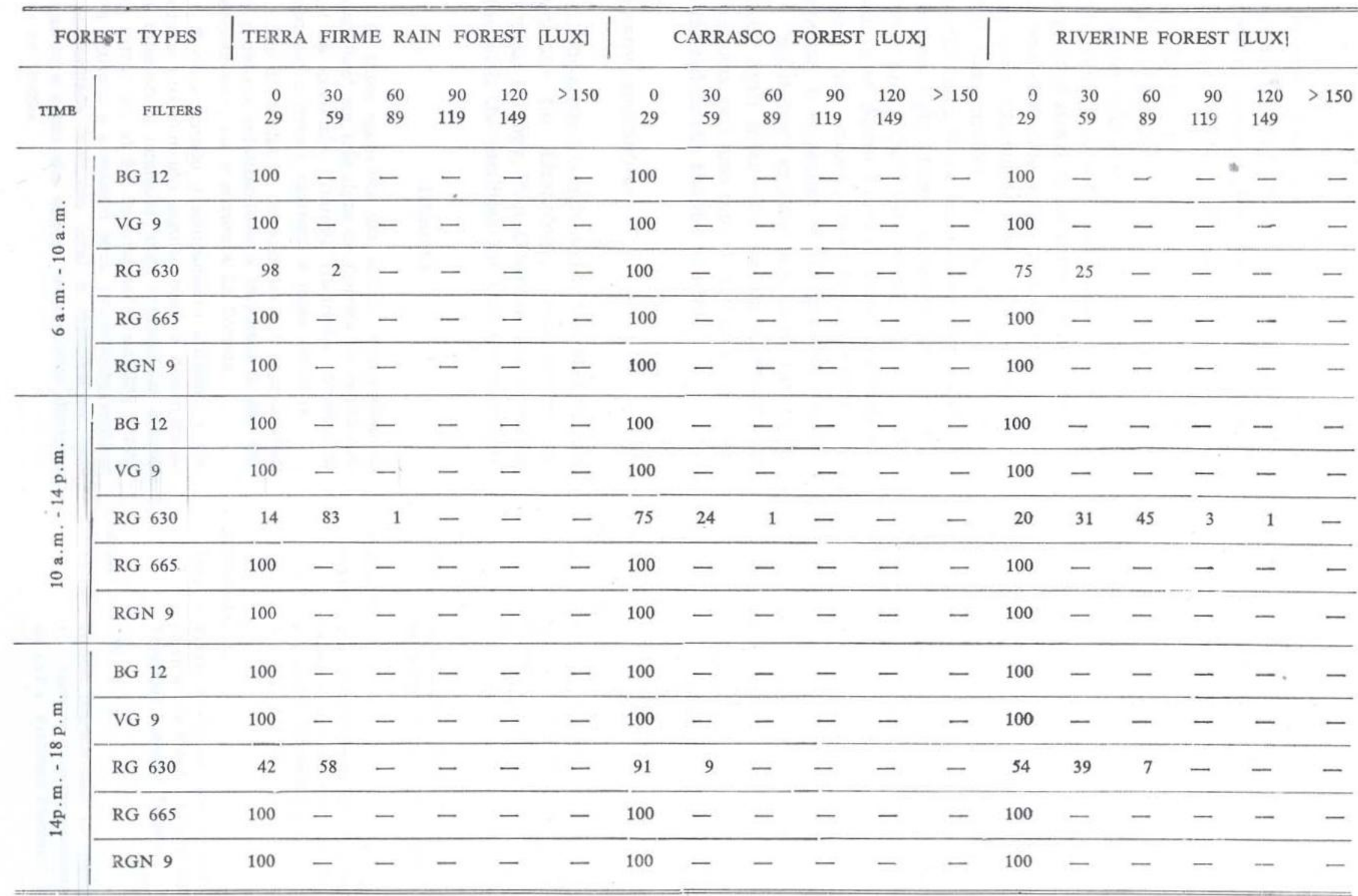

TABLE 4 - Relative frequency of spectral light intensities in the ground stratum of 1) a Riverine forest, 2) a Carrasco forest and 3 ) a terra firme Rain forest (Ducke Forest Reserve, central Amazonia), for five filter ranges of wavelenths, six intensity classes and three periods of time per day. 
For all three forest stands under observation, the spectral light intensities in the understory plant communities were calculated as relative frequencies for five filter ranges of wavelengths, six intensity classes and three periods of time per ciay (see Table 4).

Just the RG 630 filter range of warelengths $(5.920 \AA-7.500 \AA)$ reported light intensities above $30 \mathrm{Lux}$, i. e. under minimum ligth conditions the light climate inbetween the ground strata of all three forest communities was obviously uniform and ligth intensities were extremely low. The understorey plant communities of the Carrassco forest and the terra firme Rain forest, were liable to a serious light stress; consequently leaf formation and growth rates were concerned. According to Alvim (1964), these morphogenic effects are superexposed by a phytochrome response, i. e. plants of the ground stratum are "short-day" exposed not only due to reduced ligth intensities during morning and afternoon, but also que to higher proportions of far-red in the shaded habitat.

\section{ACKNOWLEDGEMENTS}

The author is indebted to the Max Planck Institute for Limnology, Departament of Tropical Ecology, Plön, Germany for providing him with the facilities for this investigation.

\section{RESUMO}

O Autor apresenta um estudo comparativo do fator "luz" em três tipos de floresta na região central da Amazônia: floresta ribeirinha (floresta da baixa terra firme), carrasco e mata primária.

São discutidas as dificuldades e a complexidade do problema enfatizando-se a importância das correlações entre luz e estrutura da floresta.

E caracterizado o equipamento utilizado e descrito o procedimento seguido para a determinaçāo da intensidade luminosa total, utilizando-se diferentes filtros em 51.840 determinações durante a esta. çăo chuvosa e a estação sêca, procurando verificar a intensidade luminosa total e espectral em cada stratum e como são aquelas intensidades distribuidas no tempo.
A frequência relativa da intensidade luminosa foi computada em sete classes de intensidade e três períodos de tempo por dia. A composição espectral da luz foi determinada como frequência relativa de intensidades por meio de filtros para cinco faixas de comprimento de ondas.

$\mathrm{Na}$ floresta ribeirinha foram encontradas as melhores condições de luz e na mata primária foram registrados os valores luminosos mais baixos. O carrasco ocupa uma posição intermediária, com nítida tendéncia às condiçōes encontradas na mata primária.

Quanto à composição espectral da luz recebida pelo stratum ao nível do solo nos três tipos de floresta, foi encontrado um pico de intensidade na faixa $5.950 \AA-7.500 \AA$, um pico secundário entre 4.420 e $6.440 \AA$ e um terceiro pico, menos importante, entre 3.500 a $5.150 \AA$

\section{BIBLIOGRAPHY CITED}

AlviM, P. DE T.

1964 - Tree growth periodicity in tropical climates. In : Zimmermann - Wood Formation. New York, Academic Press.

1967 - 1) Measurements of solar radiation in the forest. 2) Stomatal opening in relation to shade and moisture stress. In : $R / V$ "Alpha Helix" Amazon Expedition 1967, Program D1, D2.

ARAúJo, V. C. DE

1970 - The factor light as a basic element in tree growth in the Amazonian forest. Symposium Proceedings on environment in Amazônia, Manaus. Part I : 67-77.

Ashton, P. S.

1958 - Light intensity measurements in Rain forest near Santarém, Brazil. Jour. Ecol., 46(1) : 65-70.

Atrins, W. R. G. et alii

1937 - The measurements of the intensity and the colour of light in woods by means of emission and rectific photoelectric cells. Proc. $R$. Soc B., $121: 42750$.

Aubréville, A.

1961 - Etude écologique des principales formations végetales du Brésil. Nogent sur-Marne, Centro Technique Forestier Tropical.

BrinkManN, W. L. F.

$1970 \mathrm{a}$ - Optical characteristics of tropical tree leaves. I. Andiroba (Carapa guianensis Aubl.). Bol. do INPA; Pesquisas Florestais, 3 : 1-14. 
1970b- Optical characteristics of tropical tree leaves. II - Mogno (Swietenia macrophylla King). Bol. do INPA. Pesquisas Florestais, $6: 1-11$.

1970c- Optical characteristics of tropical tree leaves and barks. III - Cardeiro (Scleronema nicranthum Ducke), Ucuúba (Virola spp), Bréus (Protium spp) and Matamatás (Eschweilera spp). Bol. do INPA; Pcsuisas Florestais, 9:1-14.

1970d- Relative light intensity measurements in a secondary forest (Capoeira) near Manaus Amazônia - Brasil. Bol. do INPA; Pesquisas Florestais, $17: 1-8$.

Coutinho, L. M. \& Lamberti, A.

1967 - Some physio-ecological observations on the Amazon forest. In: $R / V$ Alpha Helix Amazon Expedition 1967, Frogram D6.

Evans, G. C.

1939 - Ecological studies on the Rain forest of southern Nigeria. II - The Atmospheric environment conditions. Jour. Ecol., 27 :436-82.

Evans, G. C. et alii

1960 - The distribution of light reaching the ground vegetation in a tropical Rain forest. Jour. Ecol $\cdot, 48$ : 193-204.

GrubB, P. J. \& Whrtmore, T. C.

1967 - A comparison of montane and low land forest in Ecuador. III - The light reaching the ground vegetation. Jour. Ecol., $55: .3357$.

IPEAN

1969 - Os solos da área Manaus-tacoatiara. Sér. Estudos e Ensaios, Belém, 1. 177 p.
Jenaer, Glaswerke Schott \& Gen.

1962 - Farb-und Filterglas für Wissenschaft und Technik. Mainz. $42 \mathrm{p}$.

KANWISHER, J.

1967 - Radiation balance in the forest. In $R / V$ Alpha Helix Amazon Expedition 1967,. Program C5.

Loomis, R. S. et alii

1967 - Light environments in Rain forests on the lower Amazon. In : $R / V$ Alpha Helix Amazon Expedition 1967, Program D11

PIRES, J. M .

1966 - APEG Report. Belém.

Rodrigues, W. A.

1967 - Inventário florestal pilôto ao longu da estrada Manaus-Itacoatiara, Estado do Amazonas: dados preliminares. Atas Simp. sôbre Bioto Amaz., 7 : (Conservação da natureza e recursos naturais) : 257-267.

SCHULZ, J. P.

1960 - Ecological studies on Rain forest in northern Suriname. Verh, der K. ned. Akad. Wet. Afdeeling Natuurkunde. Tweede Reeks Due, $53(1): 29-56$.

TAKEUCHI, M.

1961 - The structure of the Amazonian vegetatiou. II - Tropical Rain Forest. Jour. Fac. Sci . Univ. Tokyo, III, 8(1) : 1-26.

Williams, W. A. et alii

1967 - The light environment of the vegetation on the Rio Negro. In: $R / V$ Alpha Helix Amazon Expedition 1967 Program D25. 